\title{
LUT
}

Lappeenranta

University of Technology

\section{Release of Perfluoroalkyl Substances From Melting Glacier of the Tibetan Plateau: Insights Into the Impact of Global Warming on the Cycling of Emerging Pollutants}

Chen Mengke, Wang Chuanfei, Wang Xiaoping, Fu Jianjie, Gong Ping, Yan Juping, Yu Zhengliang, Yan Fangping, Nawab Javed

This is a Author's accepted manuscript (AAM) version of a publication

published by John Wiley \& Sons

in Journal of Geophysical Research: Atmospheres

DOI: $10.1029 / 2019 J D 030566$

Copyright of the original publication: () 2019 American Geophysical Union

Please cite the publication as follows:

Chen M., Wang C. Wang X., Fu J., Gong P., Yan J., Yu Z., Yan F., Nawab J. (2019). Release of Perfluoroalkyl Substances From Melting Glacier of the Tibetan Plateau: Insights Into the Impact of Global Warming on the Cycling of Emerging Pollutants. Journal of Geophysical Research: Atmospheres, Vol 124, Issue 13. p. 7442-7456. DOI: 10.1029/2019JD030566 
Wang Xiaoping (Orcid ID: 0000-0001-7524-7540)

Fu Jianjie (Orcid ID: 0000-0002-6373-0719)

\section{Release of perfluoroalkyl substances from melting glacier of the}

Tibetan Plateau: Insights into the impact of global warming on the cycling of emerging pollutants

Mengke Chen ${ }^{1,3}$, Chuanfei Wang ${ }^{1.2}$, Xiaoping Wang ${ }^{1,2.3}$, Jianjie Fu ${ }^{3,4}$, Ping Gong ${ }^{1,2}$, Juping Yan ${ }^{1,3}$, Zhengliang Yu ${ }^{1,3}$, Fangping Yan ${ }^{5}$, Javed Nawab ${ }^{6}$

${ }^{1}$ Key Laboratory of Tibetan Environment Changes and Land Surface Processes, Institute of Tibetan Plateau Research, Chinese Academy of Sciences, Beijing, 100101, China;

${ }^{2}$ CAS Center for Excellence in Tibetan Plateau Earth Sciences, Beijing, 100101, China;

${ }^{3}$ University of Chinese Academy of Science, Beijing, School of Science, Beijing 100049, China;

${ }^{4}$ State Key Laboratory of Environmental Chemistry and Ecotoxicology, Research Center for Eco-

Environmental Sciences, Chinese Academy of Sciences, Beijing 100085, China;

${ }^{5}$ Department of Green Chemistry, School of Engineering Science, Lappeenranta University of Technology, Mikkeli, Finland;

${ }^{6}$ Department of Environmental Sciences Abdul Wali Khan University, Mardan 23200, Pakistan

Corresponding authors:

Xiaoping Wang (wangxp@itpcas.ac.cn), Tel: +86-10-84097120, Fax: +86-10-84097079

Jianjie Fu (jjfu@rcees.ac.cn), Tel: +86-10-62849357, Fax: +86-10-62849157

This article has been accepted for publication and undergone full peer review but has not been through the copyediting, typesetting, pagination and proofreading process which may lead to differences between this version and the Version of Record. Please cite this article as doi: 10.1029/2019JD030566 


\section{Abstract}

The Tibetan Plateau (TP) has encountered rapid warming, with more than $50 \%$ of lakes expanding and $80 \%$ of glaciers retreating. Melting glaciers are known as a secondary source of pollutants, but the dynamics and release features of water-soluble emerging chemicals have not been studied in the TP. Glacial ice and snow, meltwater runoff, rain, and lake water were collected in Nam Co basin, in the central TP. The total concentrations of perfluoroalkyl acids (PFAAs) were $1413 \mathrm{pg} \mathrm{L}^{-1}$ for glacial ice, followed by $1277 \mathrm{pg} \mathrm{L}^{-1}$ for meltwater runoff, 980 $\mathrm{pg} \mathrm{L}^{-1}$ for lake water, and $616 \mathrm{pg} \mathrm{L}^{-1}$ for rain. Perfluorobutanoic acid (PFBA) is dominant in runoff and glacial ice, while lake water contained high proportions of perfluorobutane sulfonate (PFBS) and perfluorooctane sulfonate (PFOS). During the melting season, meltwater runoff generally had greater PFAAs concentrations, and the PFAAs release fluxes were strongly related to the glacial melt intensity. Due to the direct input of PFAAs by melted glaciers, south shore of Lake Nam Co contained higher PFAAs concentrations. The estimated input fluxes of PFAAs to the lake by rain, glacial and non-glacial runoff were $1425 \mathrm{mg} \mathrm{day}^{-1}, 1342 \mathrm{mg} \mathrm{day}^{-1}$ and $2192 \mathrm{mg} \mathrm{day}^{-1}$, respectively. Taken together, these evidences suggest that melting glaciers are sources of PFAAs, while the lake is the receptor. Given the continuity of glacial melt and high concentrations of water-soluble emerging pollutants in glacier, the melting process will increase the risks of emerging pollutants to freshwater sources, and should be of great concern.

\section{Key Points:}

- The PFASs release by glaciers has become a secondary source of PFASs in Lake Nam Co in the central Tibetan Plateau.

- PFAA transport dynamics in glacial runoff is related to the chain length of PFAAs and the melting process of ice and snow.

- Glacial meltwater, non-glacial runoff and precipitation account for $28.7 \%, 44.2 \%$ and $27.1 \%$, respectively, of the total annual PFAAs input in Lake Nam Co. 


\section{Introduction}

The cryosphere is a critical component of the global water and chemical cycles (Barbante et al., 2017; Grannas et al., 2013; Miner et al., 2017). Snow and ice are an active land surfaces upon which chemical reactions, transportation and transformations may occur (Hodgkins \& Tranter, 1998; Motoyama et al., 2001). As snow is an efficient scavenger of atmospheric pollutants, the cryosphere is an important contaminant reservoir for various kinds of pollutants (Grannas et al., 2013). Given the Earth's solid water (cryosphere) is mainly located in the Arctic, Antarctic, and on the Tibetan Plateau (TP), contamination of ice and snow in these regions has raised considerable attention (Geisz et al., 2008; Hallanger et al., 2011; Koziol et al., 2017; Kwok et al., 2013; MacInnis et al., 2017; Wang et al., 2014; Wang et al., 2008a; Wang et al., 2008b).

The "Arctic Paradox" refers to the traditionally considered pristine Arctic in fact being under serious threat from pollutants, especially those chemicals [persistent organic pollutants (POPs) and mercury] that can undergo long-range atmospheric transport (Gabrielsen, 2005). To date, POPs have been widely found in Arctic snow and ice. For example, ice cores from Svalbard (Norwegian Arctic) are useful archives of the history of POPs (Miner et al., 2017), for either legacy and currently used pesticides (Ruggirello et al., 2010) or emerging flame-retardant compounds (Hermanson et al., 2010). Like the Arctic, the ice/snow of the Antarctic and the TP has also been contaminated by POPs (Khairy et al., 2016; Wang et al., 2008a; Wang et al., 2008b); and specifically concerning the latter, the close proximity of Tibetan glaciers to the Indian subcontinent means that legacy pesticides such as DDTs and HCHs are commonly found POPs in Tibetan glaciers (Wang et al., 2007; Wang et al., 2008a; Wang et al., 2008b).

Although incorporation into the snowpack and ice creates temporary reservoirs of POPs, meltwater from glaciers can not only transport fresh water, but also contaminants. Melting mountain glaciers have become a local secondary source of POPs (Bogdal et al., 2009; Miner et al., 2019; Villa et al., 2006). Modeling results have revealed a significant loss of POPs via 
re-volatilization when the Arctic's sea-ice melts (Friedman \& Selin, 2016; Ma et al., 2011). Due to climate warming, POPs can be released into lakes and even accumulate in lake sediments (Bettinetti et al., 2011; Bogdal et al., 2009; Cheng et al., 2014; Schmid et al., 2011). Taking legacy chemicals such as PCBs and DDTs into account, their accumulation trends in sediment cores from proglacial lakes or glacier-fed lakes show a wide peak or two peaks covering the period from their ban to the most recent decade (Bettinetti et al., 2011; Bogdal et al., 2009). Such findings support the hypothesis of the release of POPs from melting alpine glaciers.

To date, many researchers have presented evidence regarding the release of POPs from melting glaciers; however, their works have focused mainly on legacy POPs with poor water solubility. To the best of our knowledge, there has only been one study on the inputs of hydrophilic perfluoroalkyl substances (PFASs) into rivers owing to melting Arctic glaciers (Kwok et al., 2013). In fact, contaminants in the Arctic derive mainly from European countries and North America, but in the meantime the manufacturing of PFASs has shifted from western countries to Asian countries (Hogue, 2012), and from longer-chain chemicals (C8 and above) to shorter chain ones (C4) (Hogue, 2012). Therefore, Asian glaciers are exposing the enhanced presence of PFASs.. As compared with concentration of shorter chain (C4) perfluorobutanoic acid (PFBA) in Arctic (1000pg L $\left.{ }^{-1}\right)$ and Antarctic snow (1112pg L $\left.{ }^{-1}\right)$ (Cai et al., 2012a; Cai et al., $2012 \mathrm{~b}$ ), high concentrations (2569 $\left.\mathrm{pg} \mathrm{L}^{-1}\right)$ of PFBA were found in fresh snow and ice cores from the remote TP, highlighting the contribution of long-range atmospheric transport and the accumulation of PFASs in the mid-latitude cryosphere (Wang et al., 2014). Tibetan glaciers are retreating owing to their vulnerability to global warming, meaning there is an urgent need to investigate the processes through which PFASs are released from Tibetan glaciers.

In the present study, samples from various environmental media, including glacial snow/ice, glacial runoff, non-glacial runoff, precipitation, and lake water were collected in Nam Co basin. The aims of the study were to: i) obtain the concentrations of perfluoroalkyl acids (PFAAs) in 
Nam Co basin; ii) test if glaciers are a secondary source of PFAAs in remote-area lakes under the impact of climate warming; iii) understand the transport dynamics of PFAAs via the runoff of melting glaciers; and iv) estimate the mass of PFAA input into remote lakes. This work will provide new insights into the impact of global warming on the cycling of emerging pollutants.

\section{Materials and methods}

\subsection{Description of study area}

Nam Co basin $\left(29^{\circ} 56^{\prime}-31^{\circ} 70^{\prime} \mathrm{N}, 89^{\circ} 21^{\prime}-91^{\circ} 23^{\prime} \mathrm{E}\right)$ is located north of GangdiseNyainqêntanglha Mountain in the central part of the TP and has a total area of about $10610 \mathrm{~km}^{2}$ (Figure 1). Dominated by the Indian monsoon in summer and westerlies in winter, Nam Co basin has a cold and arid alpine climate with a mean annual air temperature of about $-0.54^{\circ} \mathrm{C}$ and annual precipitation of about 295-550 mm (Gao et al., 2017). Meanwhile, the regional climate of Nam Co basin has strong seasonal characteristics of both temperature and precipitation. The geomorphology of the basin comprises rivers, lakes, permafrost, wetland (about 4700m), glaciers (about 5200m-7150m), alpine grassland and alpine meadow (about $4700 \mathrm{~m}$ near the lake to $5200 \mathrm{~m})$. Lake Nam Co $\left(30^{\circ} 30^{\prime}-30^{\circ} 56^{\prime} \mathrm{N}, 90^{\circ} 16^{\prime}-90^{\circ} 01^{\prime} \mathrm{E}, 4718 \mathrm{~m}\right)$, the second largest lake on the TP, is a closed, semi-brackish lake with a total area of $2017 \mathrm{~km}^{2}$ (Figure 1) and the maximum depth more than $90 \mathrm{~m}$ (Zhou et al., 2013). The Nam Co Monitoring and Research Station for Multi-sphere Interactions (NCMORS), operated by the Chinese Academy of Sciences, is located near the southeastern shore (Figure 1).

A large number of glaciers are located in this basin, and most of them are distributed in the Nyainqêntanglha Mountain Range (south of the basin). Remote sensing studies show that there are 305 glaciers in Nam Co basin, covering an area of $198.1 \pm 5.6 \mathrm{~km}^{2}$ (Bolch et al., 2010). As glacier mass balance is the result of a combined effects of climatic factors such as moisture and air temperatures, glaciers are sensitive to climate change (Oerlemans \& Fortuin, 1992). Previous study shows that glaciers in south of the basin decreased by $19.76 \pm 3.78 \%$ during the period 1999-2015 under global warming (Ji et al., 2018). Meltwater from glaciers feeds Lake Nam Co through runoff and accounts for $7-22 \%$ of the total water input into the lake. 
Meanwhile, pollutants stored in glaciers will be released and transferred to via glacial runoff into the lake's waters (Sun et al., 2017). In addition, precipitation and non-glacial meltwater are the mainly water supplies of the lake, accounting for about $27 \%$ and $36 \%$ of the total annual water input, which are also important ways for pollutants especially the water-soluble pollutants to enter the lake.

\subsection{Sample collection}

Ice and snow samples were collected from Zhadang (ZD) glacier (1.9 km², 5518-6042 m) during 2017 (Figure 1). Four snow pits (ZD1-ZD4, Figure 1) were dug from $5578 \mathrm{~m}$ to 5778 m. Given the sampling was conducted in early May, when the melting had not yet started, and at high elevation (5500-5700 m), where it was cold, the snow pit samples represented winter and spring precipitation accumulation. An obvious brown belt of dust grains was found at the bottom of snow pit ZD4 (50 cm deep, Figure S1), suggesting a strong dust storm had occurred. In the middle and top layers of the snow pits, firn and fresh snow were observed. In total, nine samples including fresh snow, firn snow, and dusty-layer snow were collected. Further details on the snow pits can be found in Text S1, Figure S1 and Table S1. Under the base of snow pit ZD4, the snow had changed to ice, indicating melting might have happened. This ice sample covered by deep snow was also collected; two other surface ice samples that were exposed to air were collected in August and October, respectively. All ice and snow samples were collected with a stainless-steel shovel, which had been cleaned before sampling, and were then stored in sterile polyethylene sampling bags. Meanwhile, precipitation samples in the form of rain were collected at NCMORS from July to September in 2017.

To investigate the PFAAs released from glaciers into Lake Nam Co via glacial meltwater runoff, water samples were collected from Qugaqie River (QR; length: 15.4 km; average channel bed slope: $\mathrm{N}$ 0.04), a glacial meltwater runoff river that drains into Lake Nam Co. Grab-water was collected along QR, from the glacier terminus (site A, Figure 1) to downstream (sites B and C, Figure 1) in August and October 2017, respectively. Given sites B and C represent the locations of two discharge gauges in the midstream section (site B, $5364 \mathrm{~m}$ ) and downstream section 
(site $\mathrm{C}, 4780 \mathrm{~m}$ ) of $\mathrm{QR}$, the temporal variation of chemical concentrations at sites $\mathrm{B}$ and $\mathrm{C}$ can indicate the transport of chemicals over time. Diurnal variations of runoff were investigated (Figure S2) and consecutive samples were collected every two hours from 08:00 to 20:00 at both site B and site C in August and October, respectively. On the south side of Lake Nam Co, there are around 12 major flows of glacial runoff; eight samples from these glacial runoff waters were collected, and other rivers located in the west, north and east parts of Lake Nam Co (eight non-glacial runoff samples in total) were also collected, for addressing the relative contribution of glacial versus non-glacial loads of PFAAs into the lake.

In order to attain a comprehensive understanding of the PFAA levels in Lake Nam Co, 14 sites (L1-L14) across the lake were selected to determine the spatial distribution of PFAAs (Figure 1); additionally, water samples were collected at a site close to NCMORS (Figure 1) about every 15 days from late July to the end of September 2017 to study the temporal variations of PFASs in the lake. All water samples were taken using 2.5-L polypropylene (PE) bottles rinsed three times with lake or river water. All samples were stored at a cold temperature $\left(\sim 4^{\circ} \mathrm{C}\right)$, in darkness, until analysis. Details regarding the sampling period, lake water properties, river water properties, and hydrological information are provided in Table S2 and Table S3. Table 1 lists some statistical information and the mean concentrations of all samples.

\subsection{Chemical Extraction and Analysis}

Snow and ice samples were melted in darkness in the lab, and then transferred to clean PE bottles. All samples were filtered through glass fiber filters $(0.7 \mu \mathrm{m}$, Whatman), and then filtered samples were subjected to solid phase extraction (SPE) using Waters Oasis WAX cartridges (150 mg, $6 \mathrm{~cm}^{3}, 30 \mathrm{~mm}$ ), as described in (Wang et al., 2014). Prior to extraction, the samples were spiked with 2000 pg of recovery standard mix (Table S4). After preconditioning with $5 \mathrm{~mL} \mathrm{MeOH}$ and $5 \mathrm{~mL}$ distilled Milli-Q water, the SPE cartridge was loaded with the water sample (2 L) and eluted at $\sim 1-2$ drops per second, after which each cartridge was washed with $0.1 \%$ acetic acid and dried for 20 min under vacuum. The cartridges and filters were then wrapped in Al-foil and sealed into airtight containers and stored at $-20^{\circ} \mathrm{C}$ until extraction. 
Before elution, each cartridge was air-dried for 30 min under vacuum. For this operation, an additional WAX cartridge was connected to the top of the sample cartridge to ensure that the air stream was free of PFAAs. Analytes were eluted from the WAX cartridges using $10 \mathrm{~mL}$ $\mathrm{MeOH}$ with $0.1 \%$ ammonium hydroxide, and then the extracts were concentrated to $200 \mu \mathrm{L}$ by nitrogen and spiked with $20 \mathrm{ng}$ of injection-standard $2 \mathrm{H}$-perfluoro-[1,2- $\left.{ }^{13} \mathrm{C}_{2}\right]$-2-decenoic acid (8:2FTUCA) $\left(50 \mu \mathrm{L}\right.$ of a $0.4 \mu \mathrm{g} \mathrm{mL}^{-1}$ solution, Table S4).

The analysis of PFAAs was conducted using a UltiMate ${ }^{\mathrm{TM}} 3000$ DGLC-HPLC (ThermoFisher Scientific, USA) and a TSQ Quantiva triple quadrupole mass spectrometer (ThermoFisher Scientific, USA). The sample $(10 \mu \mathrm{L})$ was injected onto an Acclaim $120 \mathrm{C} 18$ column $(5 \mu \mathrm{m}$, $100 \AA, 150 \mathrm{~mm} \times 4.6 \mathrm{~mm}$, ThermoFisher Scientific, USA). $10 \mathrm{mM}$ of ammoniom acetate $(\mathrm{pH}$ 4, A) and acetonitrile (B) were used as the mobile phases. The flow rate was set at $1 \mathrm{~mL} \mathrm{~min}^{-1}$. The mobile phase gradient condition started at $10 \% \mathrm{~B}$, held constant for $1.5 \mathrm{~min}$, increased to $95 \%$ by $4 \mathrm{~min}$, held constant until $8 \mathrm{~min}$, returned to the initial condition by $8.5 \mathrm{~min}$, and then balanced for $1.5 \mathrm{~min}$. The mass spectrometer (MS) was operated in the negative ion ESIMS/MS using the multiple reaction monitoring mode. The MS-related parameters were set as follows: sheath gas, 40 units; aux gas, 12 units; source voltage, $2500 \mathrm{~V}$; vaporizer temperature, $350{ }^{\circ} \mathrm{C}$; capillary temperature, $400{ }^{\circ} \mathrm{C}$; and scan time, $0.01 \mathrm{~s}$. Quantification was performed using response factors calculated and applied to a 7-point calibration curve ranging from 0 to 20 ppb for individual analytes. Target analytes included the C4-C13 perfluoro-carboxylic acids (PFCAs) and C4-C8 perfluoro-sulfonic acids (PFSAs). A full list of analytes is provided in Table S5.

\subsection{Quality Assurance and Controls (QA/QC)}

All analytical procedures were monitored using strict quality assurance/control measures. In order to reduce the pollution of the experiment itself, contact with the vessel and fluorine material during the experimental and analysis processes was avoided. Three field blanks and five laboratory procedural blanks were set. When the signal-to-noise ratio $(\mathrm{S} / \mathrm{N})$ was $<3$, target compounds were classified as not found (NF). The contaminants detected in field blanks and 
procedural blanks can be seen in Table S6, all of which were at very low concentrations $(0.07-$ 14.3 $\mathrm{pg} \mathrm{L}^{-1}$ and $0.03-2.2 \mathrm{pg} \mathrm{L}^{-1}$ for field blanks and procedural blanks, respectively). The limit of detection (LOD) was defined as three times the standard deviation of the average blank. If chemicals were classified as NF in the blanks, the LOD was calculated as an S/N ratio of 10 . The LOD of target chemicals was evaluated for each sample, the results of which are listed in Table S7. The LOD range of all targets varied from $0.3 \mathrm{pg} \mathrm{L}^{-1}$ to $16.6 \mathrm{pg} \mathrm{L}^{-1}$, which was similar to that reported in previous work (Wang et al., 2014). The blank test indicated that field sampling did not result in contamination of the samples. Recoveries ranged between $35 \%$ and $80 \%$ for the recovery mix (Table S7). All results were recovery corrected.

\subsection{Mass loading estimation}

The flux and total annual mass loadings of PFAAs that transported from runoff to the lake were calculated using the following equations:

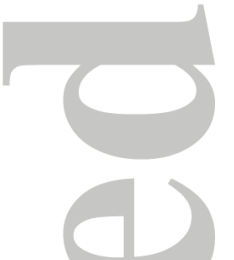

$$
\begin{aligned}
& \text { flux }=C_{w} \times Q \\
& I_{\text {water }}=C_{w} \times V_{s}
\end{aligned}
$$

Where, flux is the PFASs flux transported by runoff with the units of (mg/day); $C_{w}$ is the concentration of PFASs in water in units of $\mathrm{pg} \mathrm{L}^{-1} ; Q$ is the water flow rate of rivers with the units of $\mathrm{m} \mathrm{s}^{-1} ; I_{\text {water }}$ is the annual mass loading of a chemical in water (dissolved phase) in units of $\mathrm{kg} \mathrm{y}^{-1} ; V_{s}$ is the annual supply water to the Lake Nam Co with the units of $\mathrm{m}^{3} \mathrm{y}^{-1}$.

\section{Results and Discussion}

\subsection{PFAAs in snow, ice and rain}

Snow (fresh snow, firn snow and dusty snow) and ice samples were collected to detect the occurrence of PFAAs in ZD glacier. Thirteen target analytes were determined in snow and ice samples, and the full data on the PFAA concentrations measured are given in Table S8. The quantified PFAAs were C4, C6 and C8 PFSAs, and C4-C13 PFCAs. The average concentrations of $\sum$ PFAAs in snow and ice were $1423 \mathrm{pg} \mathrm{L}^{-1}\left(910.0-2614 \mathrm{pg} \mathrm{L}^{-1}\right)$ and 1382 
$\operatorname{pg~L}^{-1}$ (943.3-1647 $\left.\mathrm{pg} \mathrm{L}^{-1}\right)$, respectively. The snow SPFAAs concentration level in this study is lower than that previously reported for surface snow of Lake Nam Co (1875-4236 pg L $\left.{ }^{-1}\right)$ (Wang et al., 2014). However, the concentration of $\sum$ PFAAs in ice measured is higher than that reported for a TP ice core (Wang et al., 2014). The $\sum$ PFAAs for snow and ice found in the present research were also compared with those observed in polar and remote regions, as shown in Table 2. The concentrations of $\sum$ PFAAs in snow for ZD glacier are similar to those reported for the Fildes Peninsula (King George Island of Antarctica, 1129-2491 pg L ${ }^{-1}$, Table 2) and the Devon Island icecap (High Arctic, 472-2195 pg L ${ }^{-1}$, Table 2) (Cai et al., 2012a; MacInnis et al., 2017), but higher than those of the glaciers around Ny-Alesund in north of Norway (Arctic, 330-692 $\mathrm{pg} \mathrm{L}^{-1}$, Table 2) (Xie et al., 2015). The $\sum$ PFAAs concentration in surface ice is similar to that found in a study based on sea ice cores from the North Pacific to the Arctic Ocean (Cai et al., 2012b), but higher than that found for the Melville Ice Cap of the Canadian Arctic (Young et al., 2007) (Table 2).

Shorter-chain PFAAs (less than or equal toC7) accounted for a large proportion in both snow and ice samples. The compositional profiles of individual PFAAs in snow showed a trend as follows: $\mathrm{PFBA}>\mathrm{PFBS}>\mathrm{PFPeA} \approx \mathrm{PFOA} \approx \mathrm{PFHpA} \approx \mathrm{PFNA}$; while in the ice samples the trend was: $\mathrm{PFBA}>\mathrm{PFOA}>\mathrm{PFNA}>\mathrm{PFPeA} \approx \mathrm{PFDA} \approx \mathrm{PFHpA}$. PFBA was the dominant substance in both snow and surface ice, contributing $39 \%$ and $37 \%$ on average, respectively. Compared to shorter-chain PFAAs, longer-chain (C11-C13) PFAA concentrations were relatively lower, ranging from a few to tens of $\mathrm{pg} \mathrm{L}^{-1}$. This phenomenon may be related to the shift in the manufacturing of PFASs from longer-chain chemicals (C8 and above) to shorter-chain ones (C4) (Butt et al., 2010). Such results are similar to previous studies on PFAS in snow/ice of polar regions and remote areas (Casal et al., 2017; Kwok et al., 2013; MacInnis et al., 2017; Wang et al., 2014), indicating that the contamination of snow in remote regions by PFASs is ubiquitous, and PFBA is in dominance.

As precipitation is one of the most effective scavengers for the removal of particulates and 
atmospheric pollutants (Barton et al., 2007), apart from snow (from October to May) rain water during the monsoon season (August and September) was also collected. Concentrations of PFASs have been measured previously in precipitation samples from North America (Loewen et al., 2005), China (Zhao et al., 2013), and Germany (Dreyer et al., 2010). The highest PFOS concentrations (up to $113 \mathrm{ng} \mathrm{L}^{-1}$ ) were reported in rain samples from Dalian (Liu et al., 2009), China. As compared with concentrations of PFAAs in rain over urban regions (in units of ng $\mathrm{L}^{-1}$ ), the PFAA concentrations in rain over Nam Co were two to three orders of magnitude lower (within the range of tens to thousands of $\mathrm{pg} \mathrm{L}^{-1}$ ). The detailed information about PFAAs concentrations in rain samples is given in Table S8.

\subsection{Possible sources of PFAAs in precipitation}

Long-range atmospheric transport (LRAT) is researched to be the main source of PFAAs in the TP (Wang et al., 2019; Wang et al., 2014). As PFAAs have high water solubility, precipitation is the main form of deposition for PFAAs. Figure S3 shows the PFAAs composition profiles of precipitation, which includes snow (winter, from October to May) and rain collected during the monsoon season (August and September) in Nam Co basin. Clearly, the PFAAs chemical compositions in each snow layers were similar, but differed to those monitored for rain (Figure S3). Previous study indicated that no temperature-related or wind direction-connected trend was observed for PFASs in rain from urban regions (Kwok et al., 2010), but the variation in PFAS compositional profiles found for different precipitation events has been shown to be strongly source-related (e.g. traffic conditions or industrial activity) (Zhu et al., 2015). As the climate of Nam Co is influenced by westerly winds in winter and the Indian monsoon in summer, the differences in the compositional profiles of PFAAs may provide an indication of the emissions characteristics of different source regions.

Table S9 summarizes the average proportions of each PFAA in different seasons. PFHxA, PFHpA, PFHxS, PFOS, and PFTrDA were similarly proportioned in the two seasons, while distinct differences were found for other chemicals (Table S9). For the shorter-chain PFASs 
(PFBA, PFBS), the winter season showed enhanced proportions ( $\mathrm{t}$-test, $\mathrm{P}<0.05$, Table $\mathrm{S} 9$ ), whereas the summer season showed greater percentages of the longer-chain PFASs (PFOA, PFNA, PFDA etc., Table S9). Back-trajectories for precipitation events and the winter season are presented in Figure S4. The link between trajectories and the proportions of chemicals indicates that the dominance of PFBA and PFBS is likely caused by air masses from local regions, northwestern India/Nepal, and even Pakistan and central Asia; whereas, the richness of longer-chain PFASs may be due to transport from the south and east coasts of India and even some regions of Bangladesh and Myanmar (Figure S4). The ice sample collected in August displayed similar compositional patterns as the rain samples (Figure S3), showing relatively larger proportions of longer-chain PFAAs. This similarity suggests that precipitation in August (either snow or rain) reflect the feature of up-wind emission sources.

\subsection{Variation of PFAAs in snow pits and ice}

High PFAA concentrations in snow samples provides evidence that the snowpack acts as a reservoir of PFAAs. In this study, fresh snow, firn snow and dusty snow samples (from top to bottom) in snow pits were analyzed to study the potential change in PFAAs after their deposition in snow. The average concentrations and compositional profiles of PFAAs in different snow layers are shown in Figures $2 \mathrm{a}$ and $\mathrm{b}$. The average concentrations of PFAAs increased with increasing depth, with snow in the dusty layer having the highest concentration $\left(\sim 1900 \mathrm{pg} \mathrm{L}^{-1}\right)$. However, the congener profiles of fresh snow, firn snow and dusty snow were similar, indicating the PFAAs in these snow layers might have been from the same source (Figure $2 \mathrm{~b}$ ). The composition showed PFBA (accounting for $38 \%-40 \%$ of all PFAAs) was the main component, followed by PFPeA (8\%-21\%), PFBS (9\%-16\%) and PFOA (6\%-13\%). As mentioned above, the snow pit samples represented winter/spring precipitation. During that time, the atmospheric circulation pattern of Nam Co is controlled by westerly winds, which flow over northern India and central Asia countries (Figure S4). Thus, the congener profile in Figure 2 is mainly representative of the characteristics of these upwind sources. Recently, Kirkgeroge et al. (2016) measured the PFAA congener profile in a 10-m firn core from the 
glacier of Alto dell'Ortles (3830 m a.s.1., Southern Rhaetic Alps, Italy) and found that PFBA, PFOA and PFNA were the dominant chemicals. Comparing the results of our study with Kirchgeorg et al. (2016), the occurrence of a high proportion of PFBS is a distinct feature of the snow in Nam Co. PFBS derives from the photochemical oxidation of volatile precursor products of fluorobutane sulfonamide, and has been found in the atmosphere over India (Li et al., 2011). During winter, westerly flow moves southward, which can also pass over some regions of northern India (Figure S4), potentially leading to the occurrence of PFBS in the snow of Nam Co. Overall, the snow pits in Nam Co mainly recorded PFASs originating from the upwind direction (northern India).

Figure 2 displays the composition of PFAAs in the ice layer of the ZD4 snow pit. Although the chemical composition of this ice layer was broadly similar to that of the snow, the concentration of $\Sigma$ PFAAs in the ice was lower than that of the overlying snow (Figure 2). Two other ice samples were collected in August and October 2017, respectively (Figure 2); however, the dominant PFAA in the ice collected in August was PFOA (accounting for 25\%), followed by PFBA $(16 \%)$ and PFDA (10\%). As mentioned above, the concentrations of shorter-chain (C4C7) chemicals showed a clear reduction in August ice (Figure 2d). Up-wind sources of PFAAs might lead to this phenomenon, while, melting can also result in the fraction of PFAAs. Previous studies have shown that shorter-chain perfluoroalkyl congeners with higher water solubility can infiltrate with meltwater more easily, which caused the reduction in shorter-chain PFAAs (Codling et al., 2014; Kirchgeorg et al., 2016) and thus an increase in longer-chain congeners (Figure 2) during the summer season. As August is a rapid ablation period for the ZD glacier (Gao et al., 2017), the difference in the composition of surface ice samples in August may also be attributable to the melting of the glacier. Melting process and the characteristics of the chemical compositions from different source regions can jointly influence the composition of PFAAs in ice collected in August (summer season, Figure S3). The concentration of $\Sigma$ PFAAs in the ice from October was similar to that of August (Figure 2c), whereas its chemical composition was more similar to that observed for the ice layer in ZD4 [Figure 2d, PFBA 
detected with the highest proportion, accounting for $50 \%$ and $49 \%$ of $\Sigma$ PFAAs in ZD4 (ice in May) and ice in October, respectively]. This might have been due to the similar atmospheric circulation patterns during these sampling periods (Figure S4).

\subsection{Release of PFAAs and their transport via glacial runoff}

There are around 12 major meltwater streams that originate from the ZD glacier and run into Lake Nam Co. QR is one of these streams. Against the background of global warming, a melting glacier can release POPs back into environment (air and lakes) (Bogdal et al., 2009), and thus PFAAs can be transported via rivers to Lake Nam Co. Relatively high concentrations of PFASs have been found in fish from Lake Nam Co (Shi et al., 2010); however, the transportation processes of PFAAs in glacial meltwater runoff remain unclear. Accordingly, surface water samples from QR were collected, designed to assess the transport dynamics from the end of the glacier to downstream regions (refer back to section 2.2 for further details on the sampling campaign). The mean concentration of $\Sigma$ PFAAs in all runoff samples from QR was $1277 \mathrm{pg} \mathrm{L}^{-1}$ (653.5-2421 $\left.\mathrm{pg} \mathrm{L}^{-1}\right)$, which was relatively low compared with that of the snow and ice. Further details on the concentrations of PFAAs in QR are provided in Table S10 and Text S2.

\subsubsection{Spatial distribution of PFAAs in QR}

As described above, surface water samples from QR were collected at point A (upstream, glacier terminus), B (midstream, collection of small river branches from upstream region) and $\mathrm{C}$ (downstream, river outlet of the ZD basin), in two months (August and October), for testing the transport process of chemicals in and after the melting period. The results showed that PFAA levels in the glacial ice were always higher than in the meltwater from the streams of QR (Figure 3). Meanwhile, the concentration of $\sum$ PFAAs increased from the upper to middle and downstream areas in August, whereas the trend in October was different, with a peak occurring in the midstream samples (Figure 3). Glacial meltwater is representative of hundreds 
of years of deposition, whereas glacial surface ice is merely representative of the deposition that has taken place in recent years (Kohler et al., 2007). Emissions of PFASs have only happened in recent decades, meaning older ice and water, such as deep ice core samples or waters collected from deep wells, can usually be used to represent the natural background of PFASs. Thus, diluted by older ice containing much less anthropogenic PFAAs, the glacial meltwater (upstream) showed lower PFAA concentrations compared to that of surface ice.

Given the remoteness of ZD basin, and that there are no emission sources in this basin, the variation in the concentration of PFAAs from upstream to downstream may be caused by the hydrological condition of runoff and the interactions between water and other matrixes (such as soil) during the transport. In order to clarify the transport mechanism of PFAAs in QR, the variation of individual PFAA concentrations from ZD glacier to the downstream region was investigated (Figure 3). The concentrations of shorter-chain PFAAs (C4-C7) in the downstream region of $\mathrm{QR}$ (point $\mathrm{C}$ ) were generally higher than or similar to those in the midstream samples (point B, Figure 3). However, longer-chain PFAAs (C8-C11) showed a different trend, with the concentrations downstream generally being lower than those in the midstream region. The results suggest that, spatially, the transport of PFAAs in QR may be affected by the different behaviors of PFFAs with different numbers of carbon atoms. The level of absorption of shorter-chain congeners by clay and organic matter in soil is lower than that of longer-chain ones (Arp et al., 2006). Therefore, shorter-chain chemicals can be easily transported to downstream locations, while longer-chain chemicals tend to accumulate in the surface soil/vegetation of upper and midstream locations, thus displaying low concentrations downstream (Figure 3).

\subsubsection{Melting dynamics (diurnal variation) of PFAAs in QR}

Sampling on two consecutive days was carried out in the midstream and downstream regions of QR (sites B and C, Figure 1) to investigate the temporal variation of PFAAs during transport. Detailed information regarding the concentrations of PFAAs are provided in Table S10. Site B 
was located at the point of convergence between two upstream glacier rivulets (Figure 1), whereas Site $\mathrm{C}$ was situated at the river mouth, where the waters converge with those of around ten other rivers in $\mathrm{ZD}$ basin. The flow rate of the river at sites $\mathrm{B}$ and $\mathrm{C}$ was measured, as presented in Figure S2. Sampling was conducted separately in August and October, representing the extensive melting period and the end of melting, respectively. The overall input fluxes of chemicals were calculated by multiplying the river water concentration measured at sampling sites $\mathrm{B}$ and $\mathrm{C}$ with the river flow rate recorded at the time of sampling. The input fluxes, flow rate and PFAA concentrations during the period 08:00 to 20:00 are presented in Figure 4 and Figure S5. Our motivation in this respect was to find out if the fluxes of PFAAs substantially increased during the early stage of melting, and whether the concentrations of PFAAs in the runoff water or the melting intensity of the glacier controls the total release fluxes.

Figure 4 and Figure S5 show the temporal trends of the flow rates at sites B and C on different days. In August (Figure 4), the maximum flow rate occurred from 16:00 to 18:00 in the midstream area, whereas it exhibited a continuous increase after 18:00 in the downstream area (site C, Figure 4). This trend resulted in the fluxes of PFAAs remarkably increasing at the end of the melting period at the watershed scale (Figure 4). Previously, based on a lab-controlled melting experiment, the peak flow of water-soluble chemicals was found to usually take place in the early melting stage (Meyer \& Wania, 2011). This difference with our findings might be due to the lab-based experiment being too idealistic; in the field, the absorption of PFAAs by soil/vegetation may hamper their release. Figure 4 shows that the flux curves of PFAAs had a similar trend to those of flow rate; the transfer of PFAAs was strongly and highly significantly correlated with the river flow rate and chemical flux at both sites B and C (Figure S6), indicating that the transfer during melting is mainly controlled by the intensity of melting. A similar phenomenon has been observed in Highland Creek flows through the eastern part of the city of Toronto and into Lake Ontario (Meyer et al., 2011).

In October, different temporal patterns of flow rates were observed at sites B and C. Given site 
$\mathrm{B}$ was close to the glacier, the flow rate generally showed a peak at the beginning of the melting period ( 10:00, Figure S5), whereas the flow rate at site $\mathrm{C}$ remained relatively constant (Figure S5) or presented a large peak at the end of melting (18:00, Figure S5). The correlations between fluxes and flow rate, and between fluxes and $\sum$ PFAA concentrations, are provided in Figure S7 for sites B and C. Positive correlations were found between chemical fluxes and concentrations, indicating that at the end of the melting season the melting intensity is very low and PFAAs stored in the glacier contribute to the final release amount. However, in this sampling campaign, due to the harsh environment, nighttime samples were not considered; further research should take into account the melting process at night.

\subsection{Comparison between PFAAs in non-glacial and glacial runoff}

There are about 70 rivers that infuse into Lake Nam Co. Among them, QR is fed by glacial runoff, but there are 27 on the south shore that are supplied by alpine snow and glacial meltwater, as well as precipitation. The rest, located in western and northern parts of the lake, are mainly supplied by groundwater and precipitation (Figure 1). River samples were collected from 16 large rivers (Figure 1) around the lake in August 2017 in order to check if there are differences between the glacial and non-glacial rivers. The PFAA concentrations and compositions of runoff are presented in Figures 5a and b. Clearly, the concentrations of $\Sigma$ PFAAs in glacial runoff were generally higher than those of non-glacial runoff (Figure 5a, $p$ $<0.01, t$-test). Meanwhile, the compositions PFAAs also differed, with the proportion of PFBA in glacial runoff being remarkably higher than that in non-glacial runoff (Figure 5b). A similar phenomenon has been found in the Antarctic and European Alps (Cai et al., 2012a; Kwok et al., 2013). Further detail on the composition statistics is provided in Table S10, revealing that PFBA (62\%) and PFPeA (14\%) were the main PFAAs in most glacial runoff water, which was similar to the results for QR; meanwhile, the dominant PFAAs in non-glacial runoff were PFPeA (23\%) and PFBS (21\%, Table S11).

According to the flow rate of each river, we calculated the flux of PFAAs into the lake (Table S11). The flux of PFAAs in runoff around the lake varied widely: the greatest flux was about 
$1728.5 \mathrm{mg} \mathrm{day}^{-1}$, which was found for the largest river in Lake Nam Co (R10, non-glacial); and the smallest was just $0.1 \mathrm{mg} \mathrm{day}^{-1}$, also found for a small non-glacial river (R14). Regarding the input fluxes of glacial rivers, values ranged from 20 to $\sim 1000 \mathrm{mg} \mathrm{day}^{-1}$ (Table S11, maximum found for R7). Although the flow rate of R7 was a quarter of that of R10, the flux of R7 was around a half of that of R10, which caused the relatively high concentration of PFAAs in the glacial river (Table S11). The flux of PFAAs in runoff in August correlated positively with the discharge flow rate $\left(R^{2}=0.85 ; n=16, p<0.05\right)$, but had no significant correlation with $\Sigma$ PFAA concentrations (Figure S8). This suggests that the inflow flux of PFAAs is mainly controlled by river discharge in August, which is similar to the result found for QR, further confirming that the melting intensity of glaciers is a key factor controlling the inflow flux of PFAAs during the melting season.

\subsection{PFAAs in Lake Nam Co}

Lake Nam Co is mainly supplied by precipitation and runoff. In order to detect the spatiotemporal distribution and variation of PFAAs in Lake Nam Co, 19 surface water samples were collected from July to September 2017. The concentrations of PFAAs in Lake Nam Co ranged from 353.0 to $2171 \mathrm{pg} \mathrm{L}^{-1}$, with a mean value of $979.8 \mathrm{pg} \mathrm{L}^{-1}$ (see Table $\mathrm{S} 12$ for more information). In general, the results are comparable to previous studies on lakes in polar regions. For instance, the $\Sigma$ PFAA concentrations of Lake Nam Co are slightly lower than those reported for a lake in Longyearbyen, Svalbard Arctic (2495.6 $\mathrm{pg} \mathrm{L}^{-1}$ ) (Kwok et al., 2013), but higher than for the Meromictic Lakes in High Arctic Canada (27-754 pg L ${ }^{-1}$ ) (Veillette et al., 2012). However, the results of the present study are one to two orders of magnitude lower than those reported for East Lake in central China (30.12-125.35 $\mathrm{ng} \mathrm{\textrm {L } ^ { - 1 }}$ ) (Zhou et al., 2016) and Washington Park Lake in America (9.49-35.9 ng L ${ }^{-1}$ ) (Kim \& Kannan, 2007). PFBA and PFOS were the dominant compounds in Lake Nam Co, contributing $19 \%$ and $17 \%$ of all PFAAs, respectively. This is slightly different from the profile of PFAA concentrations for lakes in Fildes Peninsula, Antarctica, which are dominated by PFBA and PFTrDA (Cai et al., 2012a), but similar to those of the Meromictic Lakes in High Arctic Canada (Veillette et al., 2012). 
The TP is often referred to as the "Third Pole of the Earth", being remote and far from pollution sources; however, as PFAAs mainly derive from atmospheric transport, either directly or in terms of their precursor compounds (Wang et al., 2014), it is relevant to study their presence. The concentrations and compositional profiles of PFAAs across Lake Nam Co for the present study are presented in Figures 5c and d. As we can see, the PFAA concentrations were generally high in the southern part of the lake, where glacial meltwater runoff flows into the lake (Figure $5 \mathrm{c}, p<0.01, t$-test), suggesting that the release of PFAAs stored in glaciers has a distinct impact on the concentrations of PFAAs in lake water. This result confirms that Tibetan glaciers have become secondary sources of organic pollutants to downstream environments. Again, the PFBA composition (mean \pm SD: $23 \% \pm 13 \%$ ) in southern Lake Nam Co was significantly higher $(p<0.01, t$-test) than that in the northern part (mean \pm SD: $16 \% \pm 7 \%)$. The mean proportions of PFBA in ice, snow and glacial runoff samples were 37\%, 39\% and 59\%, respectively, potentially leading to the high proportions of PFBA in the lake's southern waters. Although precipitation also contributes to the level and composition of PFAAs in the lake, it cannot have caused this spatial difference found from south to north. Therefore, the enhanced PFBA levels in the southern part of the lake can be largely attributed to the release of PFBA from the glacier. Besides, there were two points in the northern part of the lake (L10 and L14, Figure 1) where the PFAA concentrations were relatively high possibly because of local PFAA contamination at the nearby towns of Baoji and Nam $\mathrm{Co}-\mathrm{a}$ result similar to that previously reported for polycyclic aromatic hydrocarbons in this region (Ren et al., 2017). Compared to the spatial distribution, the temporal variation of PFAAs in the Lake Nam Co from late July to the end of September varied slightly and has no significant regularity (figure S9).

\subsection{Annual mass loadings of PFAAs in glacial meltwater runoff into the lake}

The inputs of PFAAs via precipitation, glacial runoff and non-glacial runoff into Lake Nam Co were estimated based on (1) concentration data composed of the mean concentrations of $\sum$ PFAAs in precipitation, non-glacial runoff and glacial runoff determined in the present study and (2) hydrological data comprising mean values for Lake Nam Co from 1992 to 2004 (Table 
S13) reported by (Zhu et al., 2010); with (3) PFAAs absorbed by solid particles in water samples neglected. Under these conditions, the estimated total annual input of $\Sigma$ PFAAs into Lake Nam Co was approximately $1.81 \mathrm{~kg} \mathrm{yr}^{-1}$, with an annual input of $4959 \mathrm{mg} \mathrm{day}^{-1}$ (Table S13). Compared to equivalent research in the Arctic Ocean, our result is $1.7 \times 10^{4}$ and $1.4 \times$ $10^{3}$ times lower than the PFAS budgets of the surface ocean and melt pond water of the central Arctic, albeit the water volumes of which were $1.4 \times 10^{5}$ and $1.8 \times 10^{3}$ times higher than in this study, respectively (Yeung et al., 2017).

Figure 6 illustrates the contributions of precipitation, glacial runoff and non-glacial runoff to the total annual mass input of $\sum$ PFAAs from water sources. Precipitation (28.73\%) and glacial runoff $(27.07 \%)$ accounted for more than $55 \%$ of the total annual input of the lake. Previous research shows that the volume of Lake Nam Co increased at a rate of $2.37 \times 10^{8} \mathrm{~m}^{3} \mathrm{yr}^{-1}$ from 1971 to 2004 , and that glacial meltwater accounted for $52.86 \%$ of the total increase in water supply (Zhu et al., 2010), meaning the input of PFAAs into the lake by glacial meltwater increased with expansion of the lake. There are more than 1500 lakes distributed over the TP that are sensitive to climate change because of its unique environment. Research has shown that under global warming the total lake area of the TP increased from $35638.11 \mathrm{~km}^{2}$ in the early 1970 s to $41938.66 \mathrm{~km}^{2}$ in 2011 (Song et al., 2013), and glacial melt and precipitation were the main contributors to this lake expansion (Yang et al., 2014; Yao et al., 2012). As PFAAs present high concentrations in glaciers, such glacial melt under global warming will cause a more significant effect on the local environment than might otherwise be expected.

\section{Conclusion}

This study confirms that melting glaciers are secondary sources of emerging PFAAs in Tibetan lakes. Because PFAA concentrations in glacial ice/snow are greater than those of legacy POPs, the mean input fluxes of PFAAs from glaciers to lakes can reach $1342 \mathrm{mg}$ day $^{-1}$. PFBA is the dominant chemical in ice/snow and lake water directly fed by glacial runoff. Shorter-chain chemicals can easily enter lakes, and the potential risk of this for freshwater resources on the plateau should be considered. The post-deposition characteristics of PFAAs in snow and ice 
should also be studied, to clarify the transfer mechanisms of PFAAs under sunlight and melting percolation.

\section{Acknowledgement:}

This study was supported by the National Natural Science Foundation of China (41701083, 41671480 and 21677168), the Strategic Priority Research Program of the Chinese Academy of Sciences, the Pan-Third Pole Environment Study for a Green Silk Road (Pan-TPE) (XDA2004050202), and the China Postdoctoral Science Foundation (2018T110146). The data used in the paper can be found in Table S1-13 of supporting information file.

\section{References:}

Arp, H. P. H., C. Niederer, \& K. Goss (2006), Predicting the Partitioning Behavior of Various Highly Fluorinated Compounds, Environmental science \& technology, 40(23), 7298-7304. doi:10.1021/es060744y

Barbante, C., A. Spolaor, W. R. Cairns, \& C. Boutron (2017), Man's footprint on the Arctic environment as revealed by analysis of ice and snow, Earth-Science Reviews(168). doi:10.1016/j.earscirev.2017.02.010

Barton, C. A., M. A. Kaiser, \& M. H. Russell (2007), Partitioning and removal of perfluorooctanoate during rain events: the importance of physical-chemical properties, Journal of environmental monitoring: JEM, 9(8), 839-846. doi:10.1039/b703510a

Bettinetti, R., S. Galassi, P. Guilizzoni, \& S. Quadroni (2011), Sediment analysis to support the recent glacial origin of DDT pollution in Lake Iseo (Northern Italy), Chemosphere, 85(2), 163-169.

doi:10.1016/j.chemosphere.2011.06.037

Bogdal, C., P. Schmid, M. Zennegg, F. S. Anselmetti, M. Scheringer, \& K. Hungerbuhler (2009), Blast from the past: melting glaciers as a relevant source for persistent organic pollutants, Environmental science \& technology, 43(21), 8173-8177. doi:10.1021/es901628x

Bolch, T., T. Yao, S. Kang, M. F. Buchroithner, D. Scherer, F. Maussion, E. Huintjes, \& C. Schneider (2010), A glacier inventory for the western Nyainqentanglha Range and the Nam Co Basin, Tibet, and glacier changes 1976-2009, The Cryosphere, 4(3), 419-433. doi:10.5194/tc-4-419-2010 
Butt, C. M., U. Berger, R. Bossi, \& G. T. Tomy (2010), Levels and trends of poly- and perfluorinated compounds in the arctic environment, Science of the Total Environment, 408(15), 2936-2965. doi:10.1016/j.scitotenv.2010.03.015

Cai, M. H., H. Z. Yang, Z. Y. Xie, Z. Zhao, F. Wang, Z. B. Lu, R. Sturm, \& R. Ebinghaus (2012a), Per- and polyfluoroalkyl substances in snow, lake, surface runoff water and coastal seawater in Fildes Peninsula, King George Island, Antarctica, Journal of hazardous materials, 209-210, 335-342. doi:10.1016/j.jhazmat.2012.01.030

Cai, M. H., Z. Zhao, Z. G. Yin, L. Arhens, P. Huang, \& M. G. Cai, et al. (2012b), Occurrence of perfluoroalkyl compounds in surface waters from the North Pacific to the Arctic Ocean, Environmental science \& technology, 46(2), 661-668. doi:10.1021/es2026278

Casal, P., Y. F. Zhang, J. W. Martin, M. Pizarro, B. Jimenez, \& J. Dachs (2017), Role of Snow Deposition of Perfluoroalkylated Substances at Coastal Livingston Island (Maritime Antarctica), Environmental science \& technology, 51(15), 8460-8470. doi:10.1021/acs.est.7b02521

Cheng, H., T. Lin, G. Zhang, G. Q. Liu, W. L. Zhang, S. H. Qi, K. C. Jones, \& X. W. Zhang (2014), DDTs and HCHs in sediment cores from the Tibetan Plateau, Chemosphere, 94, 183-189. doi:10.1016/j.chemosphere.2013.10.012

Codling, G., C. Halsall, L. Ahrens, S. D. Vento, K. Wiberg, M. Bergknut, H. Laudon, \& R. Ebinghaus (2014), The fate of per- and polyfluoroalkyl substances within a melting snowpack of a boreal forest, Environmental pollution, 191, 190-198. doi:10.1016/j.envpol.2014.04.032

Dreyer, A., V. Matthias, I. Weinberg, \& R. Ebinghaus (2010), Wet deposition of poly- and perfluorinated compounds in Northern Germany, Environmental pollution, 158(5), 12211227 doi:10.1016/j.envpol.2010.01.030

Friedman, C. L., \& N. E. Selin (2016), PCBs in the Arctic atmosphere: determining important driving forces using a global atmospheric transport model, Atmospheric Chemistry and Physics, 16(5), 3433-3448. doi:10.5194/acp-16-3433-2016

Gabrielsen, G. W. (2005), The Arctic climate paradox, Nature, 32(6), 3, 176-179. doi: $10.1038 / 436177 \mathrm{a}$

Gao, T. G., S. C. Kang, T. J. Zhang, D. Q. Yang, J. G. Shang, \& X. Qin (2017), Stream temperature dynamics in Nam Co basin, southern Tibetan Plateau, Journal of Mountain Science, 14(12), 2458-2470.

doi:https://doi.org/10.1007/s11629-016-4234-6

Geisz, H. N., R. M. Dickhut, M. A. Cochran, W. R. Fraser, \& H. W. Ducklow (2008), Melting glaciers: a probable source of DDT to the Antarctic marine ecosystem, Environmental Science \& Technology Letters, 42(11), 3958-3962. 
doi:10.1021/es702919n

Grannas, A. M., C. Bogdal, K. J. Hageman, C. Halsall, T. Harner, \& H. Huang, et al. (2013), The role of the global cryosphere in the fate of organic contaminants, Atmospheric Chemistry and Physics, 13(6), 3271-3305.

doi:10.5194/acp-13-3271-2013

Hallanger, I. G., A. Ruus, N. A. Warner, D. Herzke, A. Evenset, M. Schoyen, G. W. Gabrielsen, \& K. Borga (2011), Differences between Arctic and Atlantic fjord systems on bioaccumulation of persistent organic pollutants in zooplankton from Svalbard, Science of the Total Environment, 409(14), 2783-2795.

doi:10.1016/j.scitotenv.2011.03.015

Hermanson, M. H., E. Isaksson, S. Forsstrom, C. Teixeira, D. C. Muir, V. A. Pohjola, \& R. S. van de Wal (2010), Deposition history of brominated flame retardant compounds in an ice core from Holtedahlfonna, Svalbard, Norway, Environmental Science \& Technology Letters, 44(19), 7405-7410. doi:10.1021/es1016608

Hodgkins, R., \& M. Tranter (1998), Solute in High Arctic glacier snow cover and its impact on runoff chemistry, Annals of Glaciology, 26, 156-160.

doi:10.3189/1998aog26-1-156-160

Hogue, C. (2012), Perfluorinated Chemical Controls, Chemical \& Engineering News, 90(37), 24-25. doi:org/10.1016/S1351-4210(12)70340-2

Ji, Q., T. B. Yang, J. Dong, \& Y. He (2018), Glacier variations in response to climate change in the eastern Nyainqentanglha Range, Tibetan Plateau from 1999 to 2015, Arct Antarct Alp Res, 50(1), e1435844. doi: org/10.1080/15230430.2018.1435844

Khairy, M. A., J. L. Luek, R. Dickhut, \& R. Lohmann (2016), Levels, sources and chemical fate of persistent organic pollutants in the atmosphere and snow along the western Antarctic Peninsula, Environmental pollution, 216, 304-313. doi:10.1016/j.envpol.2016.05.092

Kim, S. K., \& K. Kannan (2007), Perfluorinated acids in air, rain, snow, surface runoff, and lakes: relative importance of pathways to contamination of urban lakes, Environmental science \& technology, 41(24), 8328-8334.

doi:10.1021/es072107t

Kirchgeorg, T., A. Dreyer, J. Gabrieli, N. Kehrwald, M. Sigl, M. Schwikowski, C. Boutron, A. Gambaro, C. Barbante, \& R. Ebinghaus (2013), Temporal variations of perfluoroalkyl substances and polybrominated diphenyl ethers in alpine snow, Environmental pollution, $178,367-374$. doi:10.1016/j.envpol.2013.03.043

Kirchgeorg, T., A. Dreyer, P. Gabrielli, J. Gabrieli, L. G. Thompson, C. Barbante, \& R. Ebinghaus (2016), Seasonal accumulation of persistent organic pollutants on a high altitude glacier in the Eastern Alps, Environmental pollution, 218, 804-812. doi:10.1016/j.envpol.2016.08.004

(C) 2019 American Geophysical Union. All rights reserved. 
Kohler, J., T. D. James, T. Murray, C. Nuth, O. Brandt, N. E. Barrand, H. F. Aas, \& A. Luckman (2007), Acceleration in thinning rate on western Svalbard glaciers, Geophysical Research Letters, 34(18). doi: $10.1029 / 2007 \mathrm{gl} 030681$

Koziol, K., K. Kozak, \& Z. Polkowska (2017), Hydrophobic and hydrophilic properties of pollutants as a factor influencing their redistribution during snowpack melt, Science of the Total Environment, 596-597, 158-168. doi:10.1016/j.scitotenv.2017.04.061

Kwok, K. Y., S. Taniyasu, L. W. Yeung, M. B. Murphy, P. K. Lam, Y. Horii, K. Kannan, G. Petrick, R. K. Sinha, \& N. Yamashita (2010), Flux of perfluorinated chemicals through wet deposition in Japan, the United States, and several other countries, Environmental science \& technology, 44(18), 7043-7049. doi:10.1021/es101170c

Kwok, K. Y., E. Yamazaki, N. Yamashita, S. Taniyasu, M. B. Murphy, \& Y. Horii, et al. (2013), Transport of perfluoroalkyl substances (PFAS) from an arctic glacier to downstream locations: implications for sources, The Science of the total environment, 447, 46-55. doi:10.1016/j.scitotenv.2012.10.091

Li, J., S. D. Vento, J. Schuster, G. Zhang, P. Chakraborty, Y. Kobara, \& K. C. Jones (2011), Perfluorinated compounds in the Asian atmosphere, Environmental science \& technology, 45(17), 7241-7248. doi:10.1021/es201739t

Liu, W., Y. H. Jin, X. Quan, K. Sasaki, N. Saito, S. F. Nakayama, I. Sato, \& S. Tsuda (2009), Perfluorosulfonates and perfluorocarboxylates in snow and rain in Dalian, China, Environment international, 35(4), 737-742.

doi:10.1016/j.envint.2009.01.016

Loewen, M., T. Halldorson, F. Wang, \& G. Tomy (2005), Fluorotelomer Carboxylic Acids and PFOS in Rainwater from an Urban Center in Canada, Environmental science \& technology, 39(9), 2944-2951. doi: $10.1021 / \mathrm{es} 048635 \mathrm{~b}$

Ma, J. M., H. L. Hung, C. G. Tian, \& R. Kallenborn (2011), Revolatilization of persistent organic pollutants in the Arctic induced by climate change, Nature Climate Change, 1(5), 255-260.

doi:10.1038/Nclimate1167

MacInnis, J. J., K. French, D. C. Muir, C. Spencer, A. Criscitiello, A. O. De Silva, \& C. J. Young (2017), Emerging investigator series: a 14-year depositional ice record of perfluoroalkyl substances in the High Arctic, Environmental Science Processes \& Impacts, 19(1), 22-30. doi:10.1039/c6em00593d

Meyer, T., A. O. D. Silva, C. Spencer, \& F. Wania (2011), Fate of perfluorinated carboxylates and sulfonates during snowmelt within an urban watershed, Environmental science \& technology, 45(19), 8113-8119.

doi:10.1021/es200106q 
Meyer, T., \& F. Wania (2011), Modeling the elution of organic chemicals from a melting homogeneous snow pack, Water research, 45(12), 3627-3637.

doi:10.1016/j.watres.2011.04.011

Miner, K. R., J. Blais, C. Bogdal, S. Villa, M. Schwikowski, P. Pavlova, C. Steinlin, C. Gerbi, \& K. J. Kreutz (2017), Legacy organochlorine pollutants in glacial watersheds: a review, Environmental Science Processes \& Impacts, 19(12), 1474-1483.

doi:10.1039/c7em00393e

Miner, K. R., K. J. Kreutz, S. Jain, S. Campbell, \& A. Liljedahl (2019), A screening-level approach to quantifying risk from glacial release of organochlorine pollutants in the Alaskan Arctic, Journal of exposure science \& environmental epidemiology, 29(3), 293301.

doi:10.1038/s41370-018-0100-7

Motoyama, H., O. Watanabe, K. Kamiyama, I. Makoto, K. Goto-Azuma, Y. Fujii, Y. Iizuka, S. Matoba, H. Narita, \& T. Kamed (2001), Regional characteristics of chemical constituents in surface snow, Arctic cryosphere., Polar Meteorology \& Glaciology, 15, 55-67.

Oerlemans, J., \& J. P. Fortuin (1992), Sensitivity of glaciers and small ice caps to greenhouse warming, Science, 258(5079), 115-117.

doi:10.1126/science.258.5079.115

Ren, J., X. P. Wang, C. F. Wang, P. Gong, \& T. D. Yao (2017), Atmospheric processes of organic pollutants over a remote lake on the central Tibetan Plateau: implications for regional cycling, Atmospheric Chemistry and Physics, 17(2), 1401-1415.

doi:10.5194/acp-17-1401-2017

Ruggirello, R. M., M. H. Hermanson, E. Isaksson, C. Teixeira, S. Forsstrom, D. C. G. Muir, V. Pohjola, R. van de Wal, \& H. A. J. Meijer (2010), Current use and legacy pesticide deposition to ice caps on Svalbard, Norway, J Geophys Res-Atmos, 115. doi:doi:10.1029/2010JD014005

Schmid, P., C. Bogdal, N. Bluthgen, F. S. Anselmetti, A. Zwyssig, \& K. Hungerbuhler (2011), The Missing Piece: Sediment Records in Remote Mountain Lakes Confirm Glaciers Being Secondary Sources of Persistent Organic Pollutants, Environmental science \& technology, 45(1), 203-208.

doi:10.1021/es1028052

Shi, Y. L., Y. Y. Pan, R. Q. Yang, Y. W. Wang, \& Y. Q. Cai (2010), Occurrence of perfluorinated compounds in fish from Qinghai-Tibetan Plateau, Environment international, 36(1), 4650 .

doi:10.1016/j.envint.2009.09.005

Song, C. Q., B. Huang, \& L. H. Ke (2013), Modeling and analysis of lake water storage changes on the Tibetan Plateau using multi-mission satellite data, Remote Sensing of Environment, 135, 25-35.

doi:10.1016/j.rse.2013.03.013

Sun, X. J., K. Wang, S. C. Kang, J. M. Guo, G. S. Zhang, J. Huan, Z. Y. Cong, S. W. Sun, \& Q. G. Zhang (2017), The role of melting alpine glaciers in mercury export and transport: An intensive sampling campaign in the Qugaqie Basin, inland Tibetan Plateau, Environmental 
pollution, 220(Pt B), 936-945.

doi:10.1016/j.envpol.2016.10.079

Veillette, J., D. C. G. Muir, D. Antoniades, C. Spencer, T. N. Loewen, J. A. Babaluk, J. D. Reist, \& W. F. Vincent (2012), Perfluorinated Chemicals in Meromictic Lakes on the Northern Coast of Ellesmere Island, High Arctic Canada, Arctic, 65(3).

doi:10.14430/arctic4213

Villa, S., C. Negrelli, A. Finizio, O. Flora, \& M. Vighi (2006), Organochlorine compounds in ice melt water from Italian Alpine rivers, Ecotoxicology and environmental safety, 63(1), 84-90.

doi:10.1016/j.ecoenv.2005.05.010

Wang, F., T. Zhu, B. Q. Xu, \& S. C. Kang (2007), Organochlorine pesticides in fresh-fallen snow on East Rongbuk Glacier of Mt. Qomolangma (Everest), Science in China Series D: Earth Sciences, 50(7), 1097-1102.

doi:10.1007/s11430-007-0079-8

Wang, X. P., M. K. Chen, P. Gong, \& C. F. Wang (2019), Perfluorinated alkyl substances in snow as an atmospheric tracer for tracking the interactions between westerly winds and the Indian Monsoon over western China, Environment international, 124, 294-301. doi:10.1016/j.envint.2018.12.057

Wang, X. P., C. Halsall, G. Codling, Z. Y. Xie, B. Q. Xu, Z. Zhao, Y. G. Xue, R. Ebinghaus, \& K. C. Jones (2014), Accumulation of perfluoroalkyl compounds in tibetan mountain snow: temporal patterns from 1980 to 2010, Environmental science \& technology, 48(1), 173-181. doi: $10.1021 /$ es 4044775

Wang, X. P., B. Q. Xu, S. C. Kang, Z. Y. Cong, \& T. D. Yao (2008a), The historical residue trends of DDT, hexachlorocyclohexanes and polycyclic aromatic hydrocarbons in an ice core from Mt. Everest, central Himalayas, China, Atmospheric Environment, 42(27), 66996709.

doi:10.1016/j.atmosenv.2008.04.035

Wang, X. P., T. D. Yao, P. L. Wang, W. Yang, \& L. D. Tian (2008b), The recent deposition of persistent organic pollutants and mercury to the Dasuopu glacier, Mt. Xixiabangma, central Himalayas, The Science of the total environment, 394(1), 134-143.

doi:10.1016/j.scitotenv.2008.01.016

Wang, Z., Z. Y. Xie, W. Y. Mi, A. Moller, H. Wolschke, \& R. Ebinghaus (2015), Neutral Poly/Per-Fluoroalkyl Substances in Air from the Atlantic to the Southern Ocean and in Antarctic Snow, Environmental science \& technology, 49(13), 7770-7775. doi:10.1021/acs.est.5b00920

Xie, Z. Y., Z. Wang, W. Y. Mi, A. Moller, H. Wolschke, \& R. Ebinghaus (2015), Neutral polyperfluoroalkyl substances in air and snow from the Arctic, Scientific reports, 5, 8912. doi:10.1038/srep08912

Yang, K., H. Wu, J. Qin, C. G. Lin, W. J. Tang, \& Y. Y. Chen (2014), Recent climate changes over the Tibetan Plateau and their impacts on energy and water cycle: A review, Global and Planetary Change, 112, 79-91.

doi:10.1016/j.gloplacha.2013.12.001

(C) 2019 American Geophysical Union. All rights reserved. 
Yao, T. D., L. Thompson, W. Yang, W. S. Yu, Y. Gao, \& X. J. Gao, et al. (2012), Different glacier status with atmospheric circulations in Tibetan Plateau and surroundings, Nature Climate Change, 2(9), 663-667. doi: $10.1038 /$ nclimate 1580

Yeung, L. W., C. Dassuncao, S. A. Mabury, E. M. Sunderland, X. P. Zhang, \& R. Lohmann (2017), Vertical Profiles, Sources, and Transport of PFASs in the Arctic Ocean, Environmental science \& technology, 51(12), 6735-6744. doi: $10.1021 /$ acs.est.7b00788

Young, C. J., V. I. Furdui, J. Franklin, R. M. Koerner, D. C. G. Muir, \& S. A. Mabury (2007), Perfluorinated Acids in Arctic Snow: New Evidence for Atmospheric Formation, Environmental science \& technology, 41(10), 3455-3461. doi: $10.1021 / \mathrm{es} 0626234$

Zhao, L., M. Zhou, T. Zhang, \& H. W. Sun (2013), Polyfluorinated and perfluorinated chemicals in precipitation and runoff from cities across eastern and central China, Archives of environmental contamination and toxicology, 64(2), 198-207. doi:10.1007/s00244-012-9832-x

Zhou, S. Q., S. C. Kang, F. Chen, \& D. R. Joswiak (2013), Water balance observations reveal significant subsurface water seepage from Lake Nam Co, south-central Tibetan Plateau, Journal of Hydrology, 491, 89-99. doi:10.1016/j.jhydrol.2013.03.030

Zhou, Y. S., Y. Tao, H. R. Li, T. T. Zhou, T. Jing, Y. K. Zhou, \& S. R. Mei (2016), Occurrence investigation of perfluorinated compounds in surface water from East Lake (Wuhan, China) upon rapid and selective magnetic solid-phase extraction, Scientific reports, 6, 38633. doi: $10.1038 /$ srep38633

Zhu, L. P., M. P. Xie, \& Y. H. Wu (2010), Quantitative analysis of lake area variations and the influence factors from 1971 to 2004 in the Nam Co basin of the Tibetan Plateau, Chinese Science Bulletin, 55(13), 1294-1303. doi:10.1007/s11434-010-0015-8

Zhu, Z. Y., T. Y. Wang, J. Meng, P. Wang, Q. F. Li, \& Y. L. Lu (2015), Perfluoroalkyl substances in the Daling River with concentrated fluorine industries in China: seasonal variation, mass flow, and risk assessment, Environmental science and pollution research international, 22(13), 10009-10018. doi:10.1007/s11356-015-4189-0

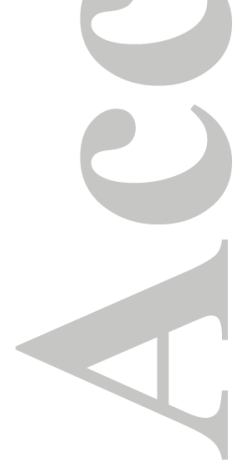


Tabe1 Sampling information and the ranges and averages of $\sum$ PFAAs concentration by sample type.

\begin{tabular}{|c|c|c|c|c|}
\hline Obj & Sample types & Sampling site & $\begin{array}{c}\text { Number of } \\
\text { samples }\end{array}$ & $\begin{array}{l}\text { Average concentration } \\
\text { of } \sum \text { PFAAs }\left(\mathrm{pg} \mathrm{L}^{-1}\right)\end{array}$ \\
\hline \multirow{3}{*}{ Glac } & Snow & ZD1-ZD4 & 9 & $1423(910.9-2614)$ \\
\hline & Ice & ZD glacier & 3 & $1382(943.3-1647)$ \\
\hline & River water & $\begin{array}{l}\text { A-C (from glacier } \\
\text { terminus to river mouth) }\end{array}$ & 61 & $1277(653.4-2421)$ \\
\hline Lake Nam Co & Lake water & L1-L14 and NCMORS & 19 & $980(353.0-2171)$ \\
\hline $\begin{array}{l}\text { Runoff around } \\
\text { the lake }\end{array}$ & $\begin{array}{l}\text { water at river } \\
\text { mouth }\end{array}$ & R1-R16 & 16 & $1023(443.2-1940)$ \\
\hline Precipitation & Rain water & NCMORS & 15 & $616(115.1-1370)$ \\
\hline
\end{tabular}


Table 2 Comparison of PFAS concentrations ( $\left.\mathrm{pg} \mathrm{L}^{-1}\right)$ obtained in this study with data from other remote regions.

\begin{tabular}{|c|c|c|c|c|c|}
\hline An & Concentration & $\begin{array}{l}\text { Sample } \\
\text { types }\end{array}$ & Site & $\begin{array}{l}\text { Study } \\
\text { period }\end{array}$ & Reference \\
\hline & $910-2614$ & $\begin{array}{l}\text { Surface } \\
\text { snow }\end{array}$ & ZD glacier in central TP & 2018 & This Study \\
\hline & $1875-4236$ & $\begin{array}{l}\text { Fresh } \\
\text { snow }\end{array}$ & Lake Nam Co in central TP & 2010 & $\begin{array}{l}\text { (Wang et al., } \\
\text { 2014) }\end{array}$ \\
\hline $\mathrm{PI}$ & $760-3600$ & $\begin{array}{l}\text { Fresh } \\
\text { snow }\end{array}$ & $\begin{array}{l}\text { Livingston Island, Maritime } \\
\text { Antarctica }\end{array}$ & $\begin{array}{l}2014- \\
2015\end{array}$ & $\begin{array}{l}\text { (Casal et al., } \\
\text { 2017) }\end{array}$ \\
\hline & $330-692$ & $\begin{array}{l}\text { Surface } \\
\text { snow }\end{array}$ & $\begin{array}{l}\text { Glaciers around } \mathrm{Ny}- \\
\text { Alesund, Arctic }\end{array}$ & 2012 & $\begin{array}{l}\text { (Xie et al., } \\
2015)\end{array}$ \\
\hline $\mathrm{PF}$ & $1129-2491$ & Snow & $\begin{array}{l}\text { King George Island, } \\
\text { Antarctica }\end{array}$ & 2011 & $\begin{array}{l}\text { (Cai et al., } \\
2012 a)\end{array}$ \\
\hline & $125-303$ & Snow & Antarctic Peninsula & 2011 & $\begin{array}{l}\text { (Wang et al., } \\
2015 \text { ) }\end{array}$ \\
\hline & $472-2195$ & Snow & Devon Ice Cap, High Arctic & 2008 & $\begin{array}{l}\text { (MacInnis et } \\
\text { al., 2017) }\end{array}$ \\
\hline & $260-1500$ & Snow & $\begin{array}{l}\text { From north Pacific to Arctic } \\
\text { Ocean }\end{array}$ & 2010 & $\begin{array}{l}\text { (Cai et al., } \\
\text { 2012b) }\end{array}$ \\
\hline & $134-848$ & $\begin{array}{l}\text { Melted } \\
\text { snow }\end{array}$ & $\begin{array}{l}\text { Meromictic Lakes, Arctic } \\
\text { Canada }\end{array}$ & 2008 & $\begin{array}{l}\text { (Veillette et } \\
\text { al., 2012) }\end{array}$ \\
\hline & $943.3-1647$ & $\begin{array}{l}\text { Surface } \\
\text { Ice }\end{array}$ & ZD glacier in central TP & 2017 & This study \\
\hline PFA & $95-166$ & $\begin{array}{l}\text { Ice } \\
\text { core }\end{array}$ & Svalbard, Norway, Arctic & 2006 & $\begin{array}{l}\text { (Kwok et } \\
\text { al., 2013) }\end{array}$ \\
\hline PFASs & $20.4-435.7$ & Ice & Melville Ice Cap, Canadian & $2005-$ & (Young et \\
\hline
\end{tabular}




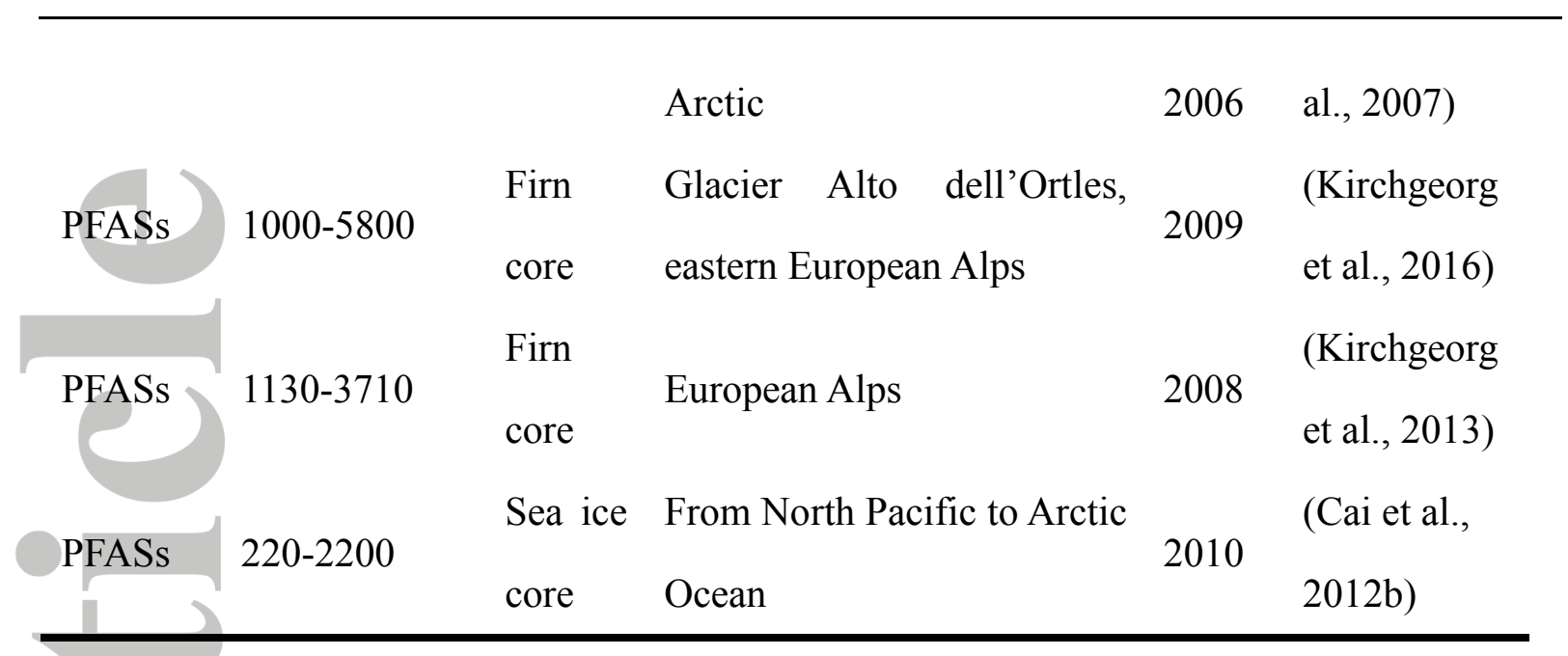

(C) 2019 American Geophysical Union. All rights reserved. 


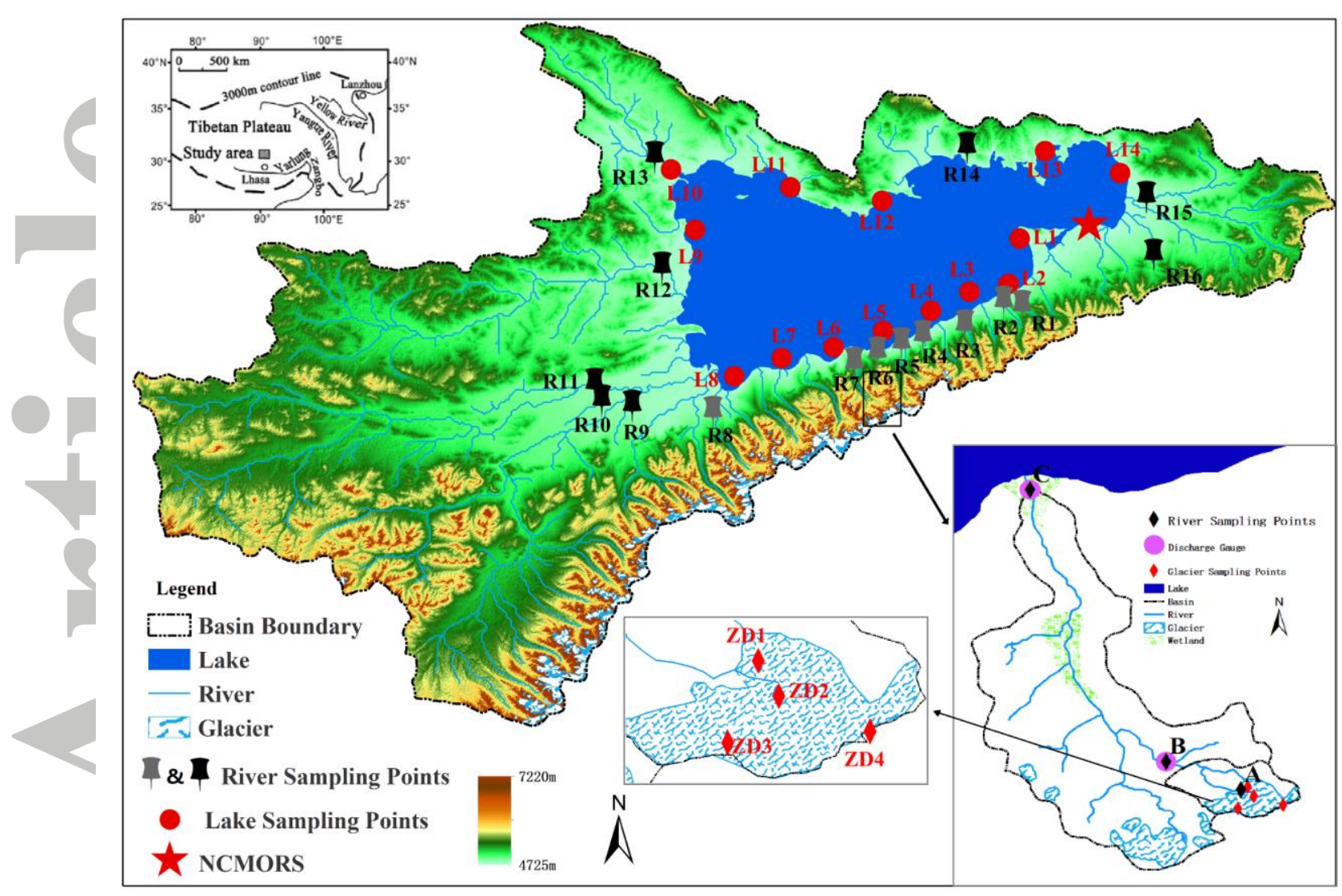

Figure 1 Topographical overview and sampling points of Nam Co basin (The grey river label means that the river is mainly fed by glacial meltwater). 

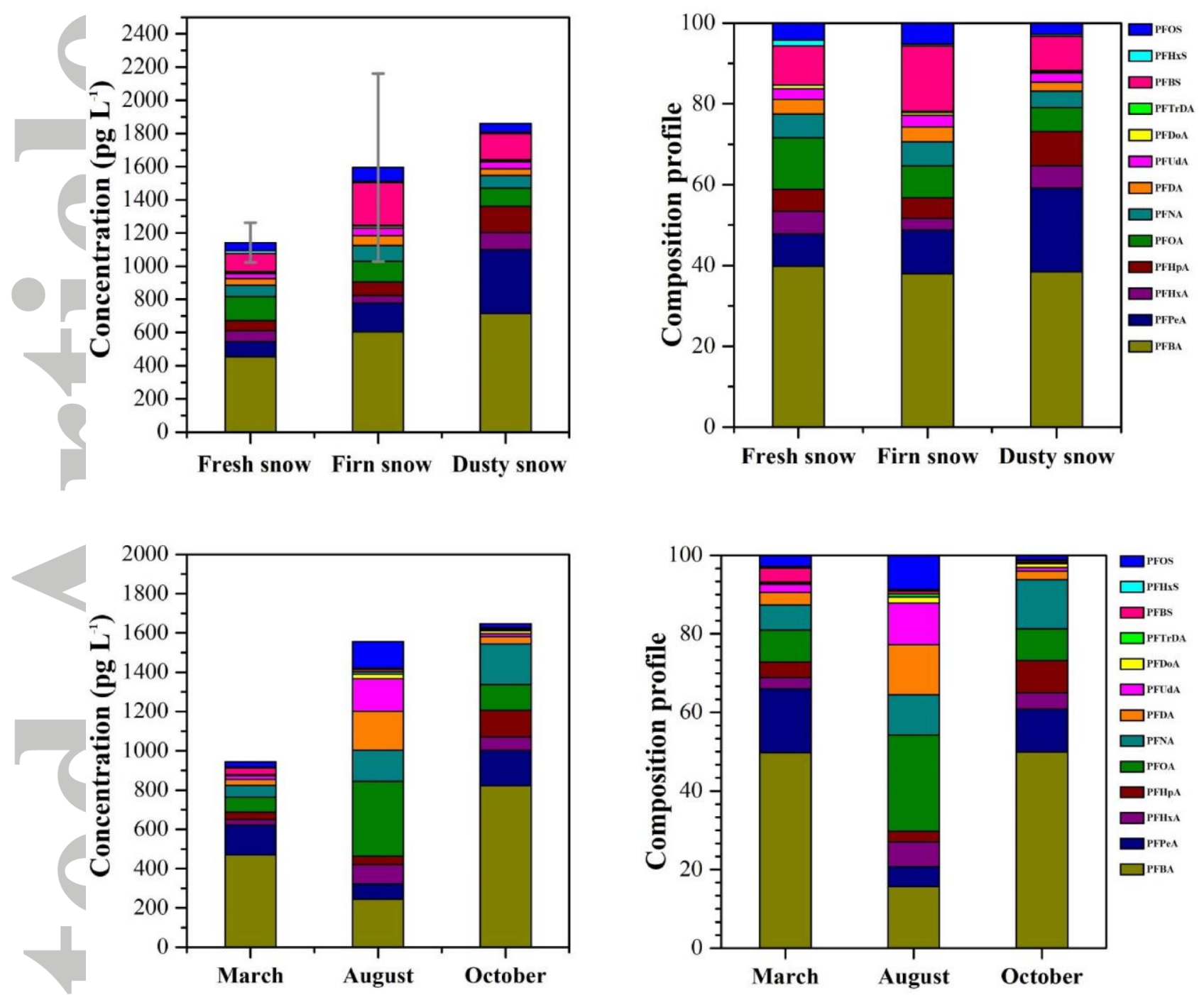

Figure 2. Concentrations and compositional profiles of PFAAs in snow [(a) and (b)] and ice [(c) and (d)], in which the gray line represents the standard deviation of the $\sum$ PFAAs concentrations. 


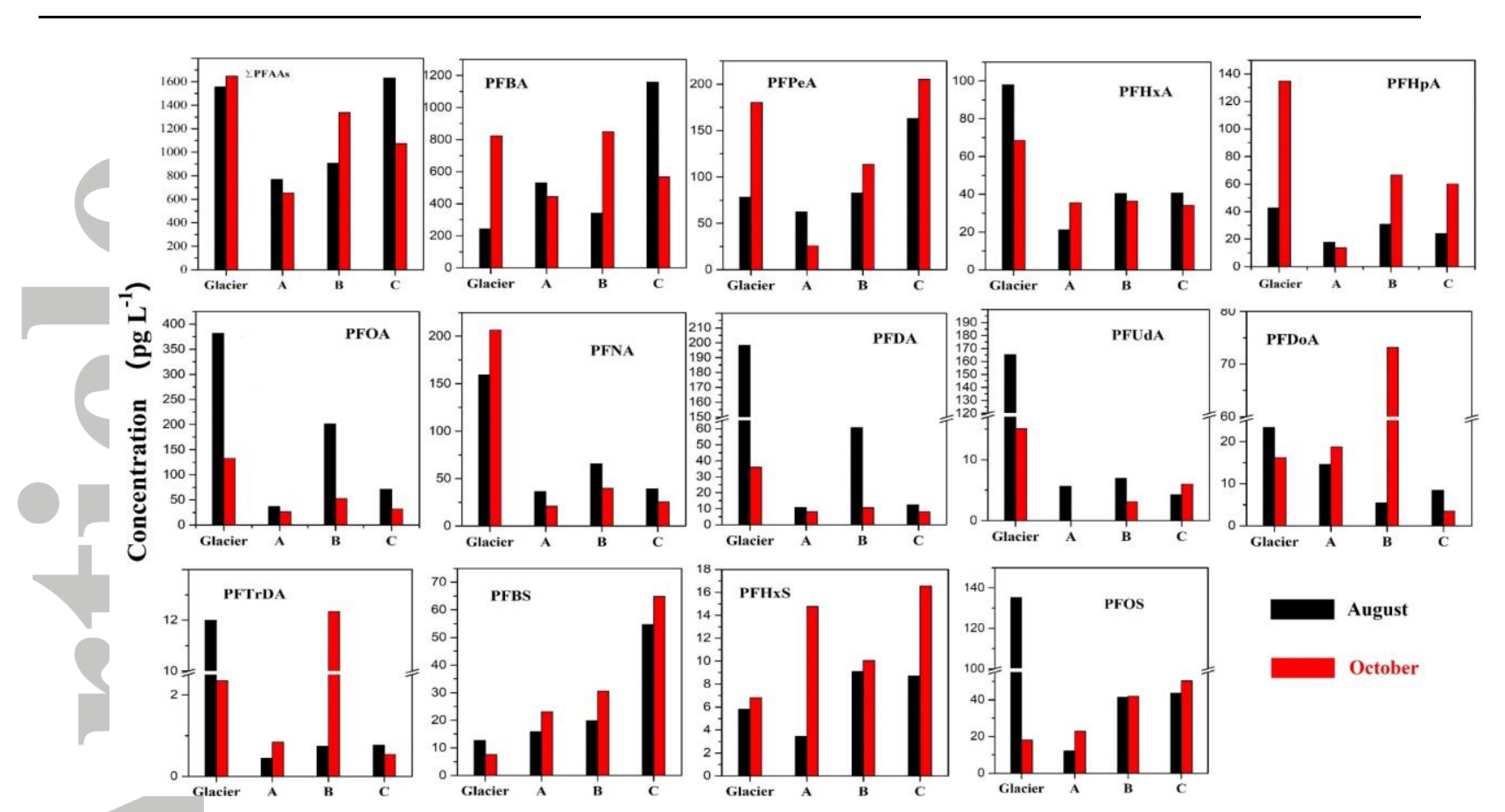

Figure 3. Concentrations of individual PFAAs in QR water from the glacier to downstream, A (upstream, glacier terminus), B (midstream, collection of small river branches from upstream region) and $\mathrm{C}$ (downstream, river outlet of the ZD basin) 

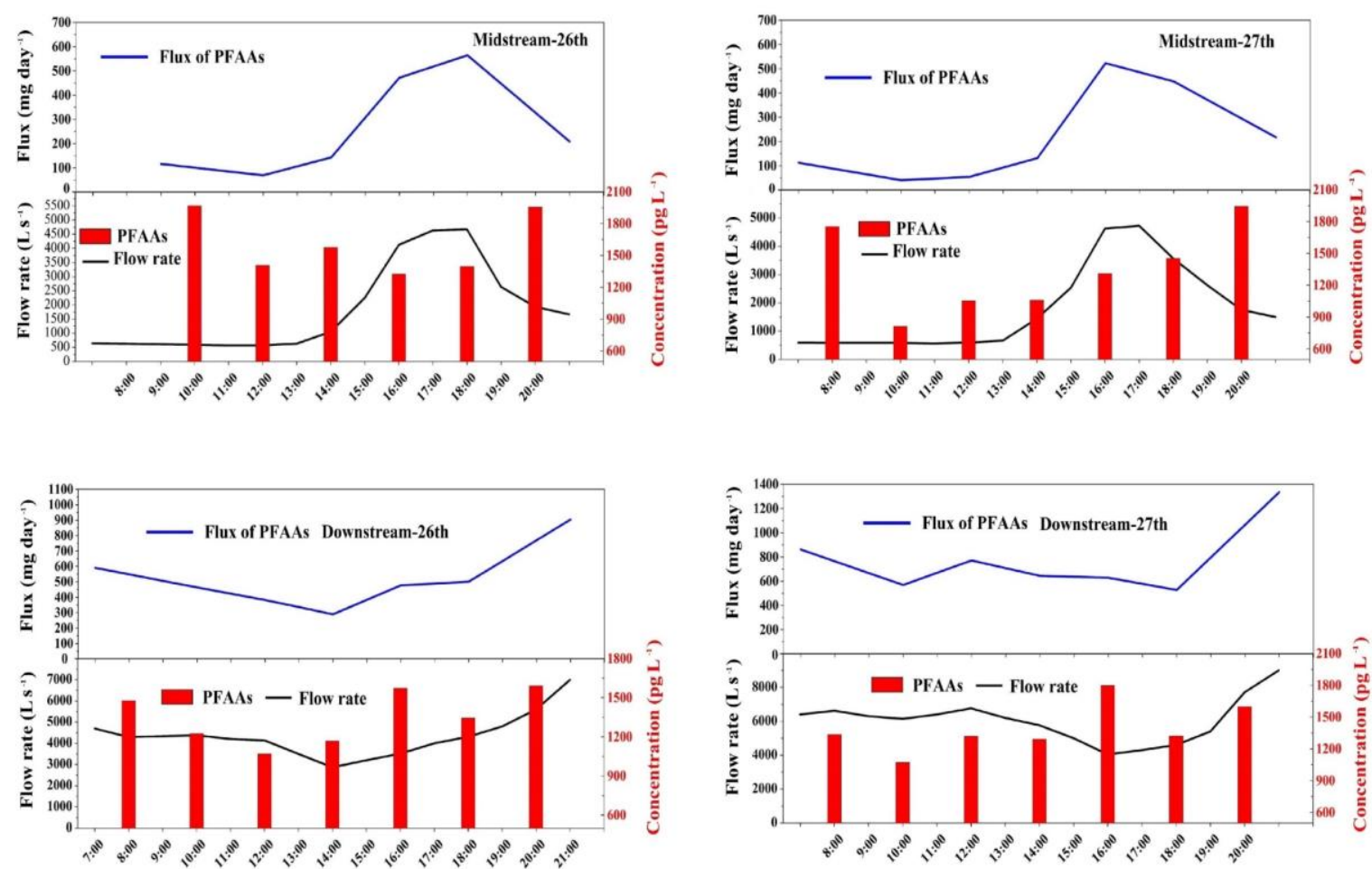

Figure 4 Diurnal variation of flow rate, PFAA concentration, and PFAA flux in the midstream and downstream of QR in August. 

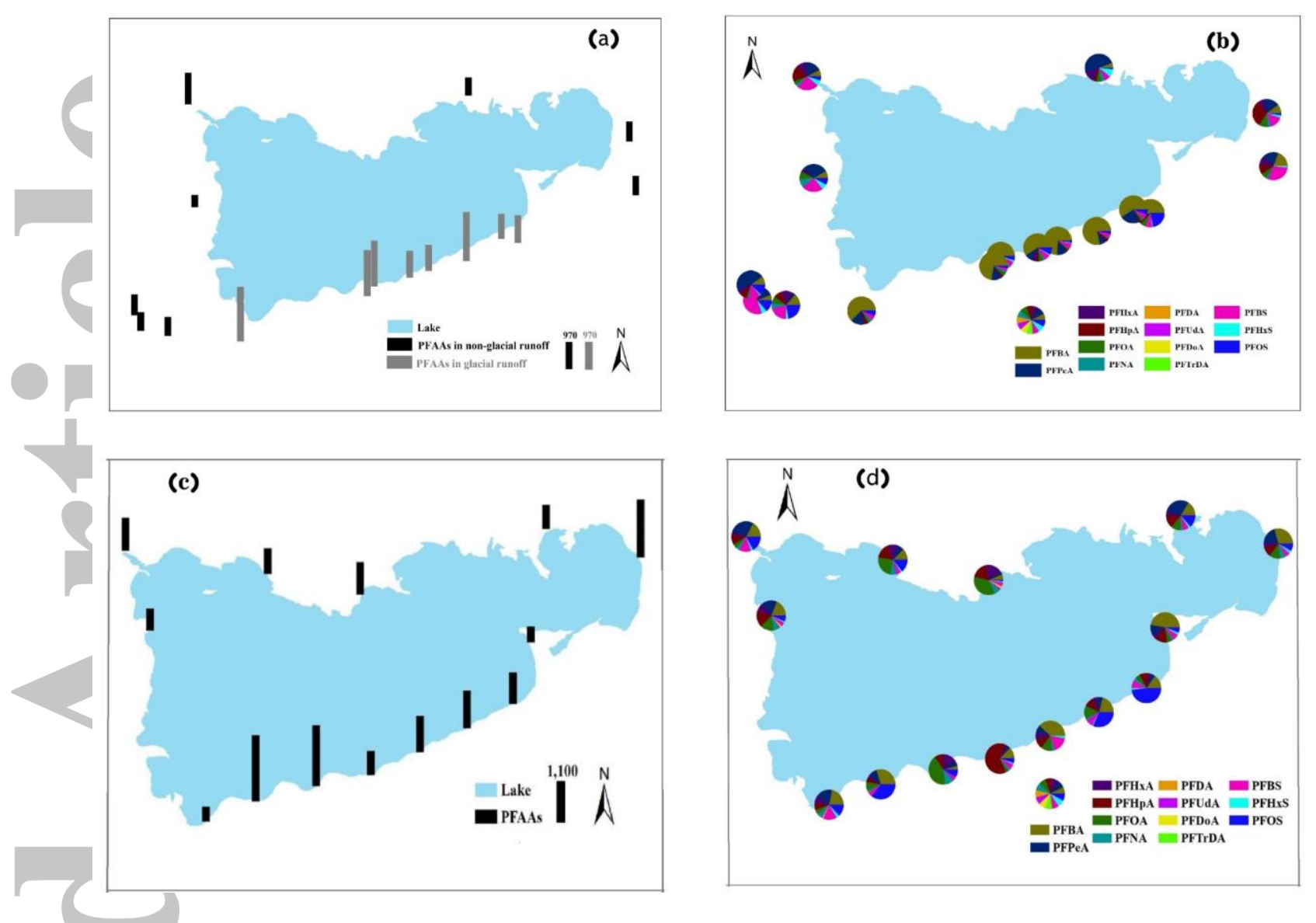

Figure 5. Spatial distribution and compositional pattern of $\Sigma$ PFAAs in runoff around $[(a),(b)]$ and in $[(c),(d)]$ Lake Nam Co. 


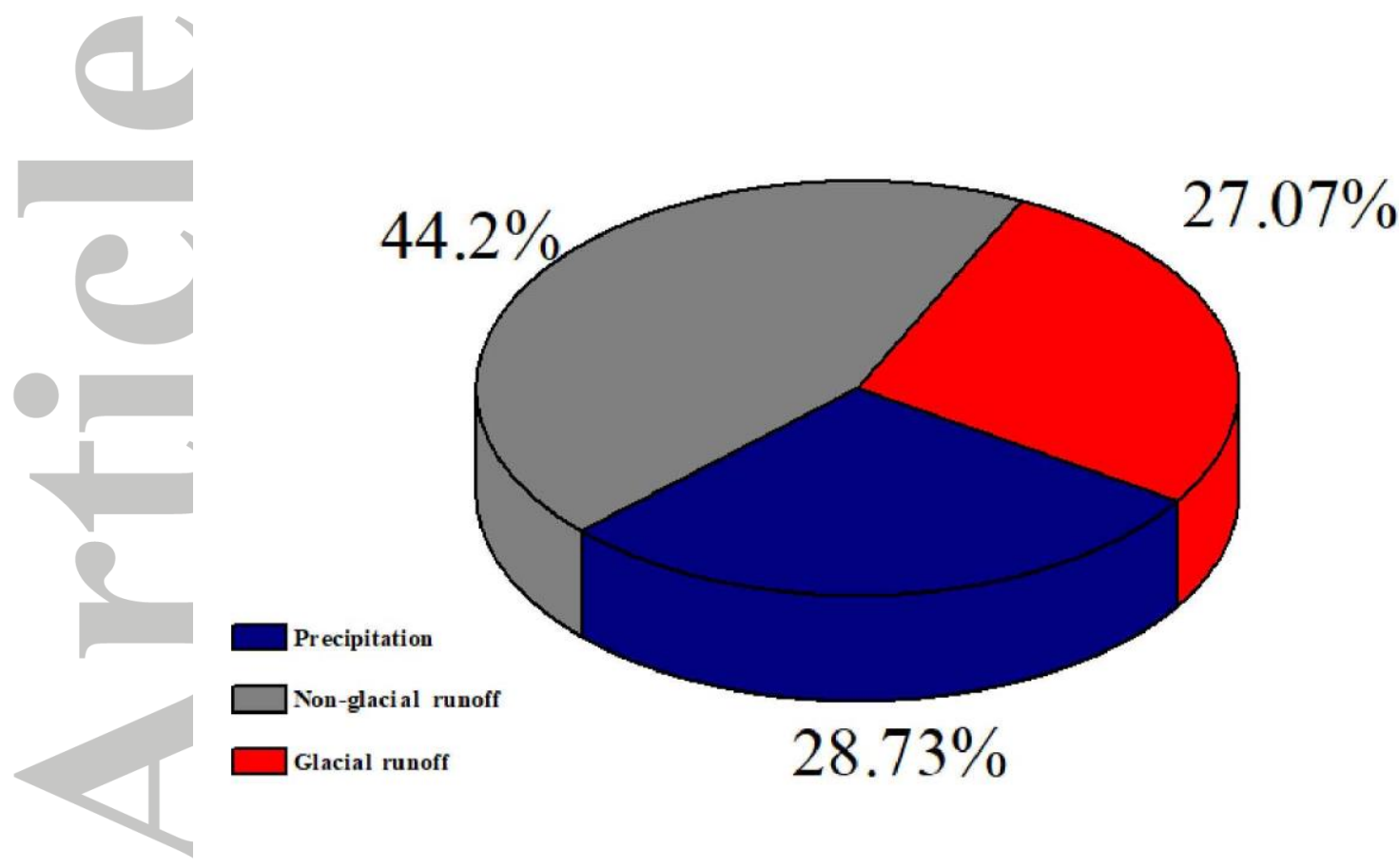

Figure 6. Annual input of $\Sigma$ PFAAs from various water sources.

(C) 2019 American Geophysical Union. All rights reserved. 